\title{
EVALUACIÓN DEL RODEO DE HEMBRAS DE LA ESTA- CIÓN EXPERIMENTAL DE RAFAELA A PARTIR DE LAS EVALUACIONES GENÉTICAS NACIONALES
}

\author{
VERA, M. ${ }^{1}$ \\ RESUMEN
}

Las evaluaciones genéticas nacionales constituyen la herramienta fundamental para lograr los objetivos de selección impuestos dentro de un plan de mejora. La Argentina no ha logrado aún implementar un plan de mejora genético nacional, a pesar de que la producción lechera constituye una de las mayores explotaciones nacionales. La utilización de un nuevo recurso como son los méritos genéticos, informa sobre los resultados del desempeño nacional en la mejora genética, y garantiza la correcta elección en función de los objetivos de selección nacional. El fin último es la competitividad del material genético nacional.

Con la finalidad de promover el uso apropiado de los méritos genéticos, este trabajo describió y analizó las evaluaciones genéticas de hembras de un rodeo en particular, con respecto al total de vacas evaluadas por control lechero oficial. Los resultados indicaron la posibilidad de obtener mayor repuesta a la selección.

Palabras clave: méritos genéticos, evaluaciones genéticas nacionales.

\section{SUMMARY}

\section{Evaluation of the female herd at Rafaela Experimental Station, from Official Milk Recording System}

National Genetic Evaluations are the main tool to reach improvement objectives into a genetic plan. Dairying is one of the most important animal production activity in Argentina, but Genetic Evaluations are not massively used. Every type of information that clarify or promotes breeding values application will be consider an important contribution. This work describe and analyze female breeding values of a Holstein herd within Official Milk Recording System. Results indicate that possibilities exists for better selection response. Breeding values application will report national performances and guarantee animal choice according to the national selection objectives. The ultimate aim persued is to raise the national genetic level in milk production.

With the purpose of promoting the appropriate use of the genetic merits, this work described and analyzed the genetic evaluations of females herd, with respect to the total of cows evaluated by Official Milk Recording System. The results indicated the possibility of obtaining greater replaced to the selection.

Key words: breeding value, official milk recording system.

1.- INTA - EEA Rafaela. C.C. 22 (2300) Rafaela, provincia de Santa Fe.

E-mail: mvera@rafaela.inta.gov.ar

Manuscrito recibido el 24 de febrero de 2006 y aceptado para su publicación el 3 de julio de 2006. 